\title{
The effectiveness Village-Owned Enterprises (BUMDes) Sehati in Nekmese Village Amarasi Sub-District, South Kupang Regency
}

\author{
Yopy E. Haekase ${ }^{1}$, Nursalam ${ }^{2}$, Hendrik Toda ${ }^{3}$ \\ Nusa Cendana University ${ }^{1,2,3}$ \\ yopy90haekase@gmail.com ${ }^{1 *}$, nursalamjeppu@yahoo.com ${ }^{2}$, hendrik.toda2012@gmail.com $^{3}$
}

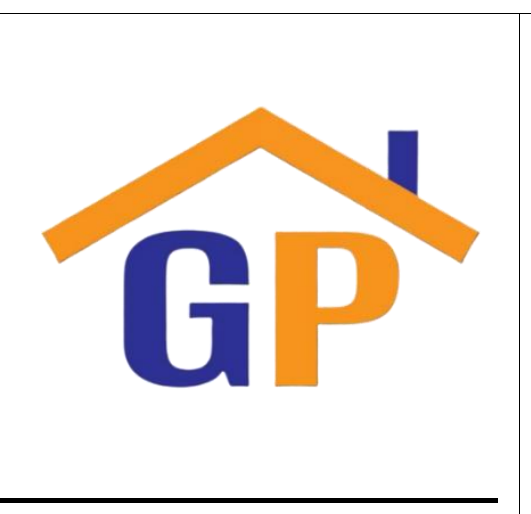

Article History

Received on 13 October 2020

$1^{\text {st }}$ Revision 28 October 2020

$2^{\text {nd }}$ Revision on 21 December 2020

$3^{\text {rd }}$ Revision on 23 December 2020

Accepted on 30 December 2020

\begin{abstract}
Purpose: The purpose of this study is to measure and analyze the effectiveness of Sehati Village-Owned Enterprises (BUMDes) in Nekmese Village, South Amarasi District, Kupang Regency.

Research Methodology: This study used descriptive research with a qualitative approach that used the effectiveness measurement criteria of Chambell J.P (1989).

Results: The findings in this study are that BUMDes has been effective with several successes, namely program success, target success, satisfaction with the program and the achievement of.

Limitations: This research only reviewed the effectiveness of BUMDes Sehati in Nekmese village, Kupang Regency.

Contribution: This research becomes scientific information for public administration science.

Keywords: Effectiveness, BUMDes

How to cite: Haekase, Yopy E., Nursalam., Toda, Hendrik. (2020). Effectiveness of the implementation of Village-Owned Enterprises (BUMDes) Sehati in Nekmese Village Amarasi SubDistrict, South Kupang Regency. Journal of Sustainable Tourism and Entrepreneurship, 1(3), 217-230.
\end{abstract}

\section{Introduction}

In the system of government of the unitary state of the Republic of Indonesia, the village has a strategic role as an element of the local government, especially the Regency/ City in organizing the development process. All of this is done as a real step by the central government to support regional autonomy implementation. The village government is the lower strata of government that is directly related to the community. So the level of public trust in the management of the village government is very important and needed. Widjaja (2003:3) states that the village is a unit of the legal community that has an original arrangement based on the privileged origin rights. The cornerstones of the village government are diversity, participation, genuine autonomy, community empowerment and democratization.

Village Development is an effort to improve the welfare of all peoples, nations, and countries to achieve the national goals stated in the Opening of the 1945 Constitution. Villages have an important role in national development efforts because Indonesians tend to live in rural areas so that it exerts considerable influence in efforts to create national stability.

Village economic growth is often judged to be slower than urban economic development. To improve this, two approaches are needed; (a) the needs of the community in making efforts to change and prevent unwanted things, and (b) Political will and the ability of the village government with the community in implementing the development planning that has been drawn up (Rutiadi, in Bachrein, 2010).

Guidelines for regions and villages in the establishment and management of BUMDes trtuang in Village Minister Regulation No. 4 of 2015 on The Establishment, Management and Management, and Dissolution of Village-Owned Enterprises. In this ministerial regulation it is stated that BUMDes as a 
business entity, all or most of its capital is owned by the village through the direct inclusion of the village wealth, therefore, the development of BUMDes is a form of strengthening of the village economic institutions and is a means of utilizing the local economy with various types of potential in the village, more than that BUMDes becomes the backbone of the village government economy to achieve the improvement of the welfare of its citizens.

In Law of the Republic of Indonesia No. 6 of 2014 on Villages, the village government is encouraged to have BUMDes which are then further regulated in the Regulation of the Minister of Villages, Development of Disadvantaged Areas, and Transmigration of the Republic of Indonesia No. 4 of 2015 on The Establishment, Management and Management, and Dissolution of Village-Owned Enterprises. In the ministry of villages, development of disadvantaged areas, and transmigration (Kemendes PDTT) until December 2018 as many as 61 percent of villages in Indonesia already have village-owned enterprises (BUMDes), or have formed as many as 50,199 units of BUMDes in Indonesia. This number increased sharply from 2014, which had only 1,022 BUMDes (Kemendesa.go.id). From various regions in Indonesia that run BUMDes, one of them is Kupang Regency of East Nusa Tenggara Province.

The basis of the establishment of BUMDesa is based on the needs and potential of the village, as an effort to improve the welfare of the community. With regard to its planning and establishment, BUMDesa is built on community initiatives, and based on cooperative, participatory and transparency principles. In addition, the management of BUMDesa must be done professionally and independently. BUMDesa is a pillar of economic activity in the village that serves as a social institution and commercial institution. BUMDesa as a social institution sided with the interests of the community through its contribution in the provision of social services. Thus it can be concluded that BUMDes is a business entity managed by a group of people appointed and trusted by the provincially managed village government and family to multiply the potential of the village and advance the village economy by structured and managed (Rutiadi, 2001 in Bachrein, 2010)

Based on the data released by Kupang district and community empowerment office, it is known that there are 160 villages in Kupang regency spread across 24 sub-districts but until now there are only 148 villages in Kupang Regency that run BUMDes one is Nekmese Village South Amarasi District namely BUMDes Sehati.

BUMDes Sehati Nekmese Village is required to not only provide standard services but excellent services that prioritize the quality needed to provide better results in order to achieve the effectiveness of implementing BUMDes Sehati Nekmese Village. In this case the effectiveness is the utilization of certain amounts of resources, facilities and infrastructure that are consciously set beforehand to produce a number of work in time so that it can be concluded that effectiveness relates to the implementation of all the basic tasks, the achievement of objectives, timeliness, and active participation of members and is the relationship between the stated goals and results, and shows the degree of conformity between the stated goals and the results achieved (Abdurahmat, 2008:7).

Based on the background description above, the authors feel interested to conduct research with the title "Effectiveness of The Implementation of Village-Owned Enterprises "Bumdes Sehati" In Nekmese Village South Amarasi District Kupang Regency". To analyze the effectiveness, the authors used Campbell J.P.'s effectiveness measurement criteria (1989:121) namely: (a) program success, (b) goal success (3) satisfaction with the program and (d) achievement of comprehensive goals.

\section{Literature review}

\subsection{Effectiveness}

Effectiveness is a level of success generated by a person or organization in a certain way in accordance with the objectives to be achieved. In other words, the more successful plans are achieved, the more effective an activity will be. According to the Great Dictionary of Indonesian Language (Kamus Besar Bahasa Indonesia), Effectiveness is the use, activeness and conformity in an activity between a people carrying out a task with the objectives that he or she wishes to achieve.

The effective word comes from English which is effective which means to succeed or something done works well. Popular scientific dictionary defines ephemerality as the accuracy of use, results of use or supporting purpose. Soewarno Handayaningrat S. (1994:16) states that "Effectiveness" is a measurement in the sense of achieving a forefined goal." This is in accordance with the opinion expressed by Hidayat (1986:30), which explains that Effectiveness is a measure that states how far the 
target (quantity, quality and time) has been reached. Where the greater the percentage of targets achieved, the higher the effectiveness.

The work that is said to be effective is not necessarily efficient, because it may be the result achieved by scattering materials, also in the form of thoughts, energy, time, or other objects. The word effectiveness is often followed by the word efficiency, where both words are strongly related to the productivity of an action or desired result. An effective is not necessarily efficient, nor is an efficient one not necessarily effective. Thus the effective term is to do the right and appropriate work and in the right way to achieve a planned goal. While efficient is the result of efforts that have been achieved greater than the efforts made.

Effectiveness is the main element to achieve the goals or goals that have been determined in each organization. Effectiveness is also called effective, when achieved goals and goals. This is in accordance with Soewarno's opinion that effectiveness is a measurement in the sense of achieving a previously determined goal. Caster I. Bernard also expressed the same opinion; effectiveness is the achievement of a mutually agreed goal (Bernard, 1992:207).

Measuring organizational effectiveness can be done in a variety of approaches. Some of them are based on goal approach, system resource approach, or internal process approach. In addition, a more integrative and widely accepted approach was developed. The approach is stakeholder approach and competing-values approach (Silalahi, 2015:418). Furthermore, Tangkilisan and Nogi (2005:141) presented 5 (five) criteria in measuring effectiveness, namely:

a. Productivity

b. Work adaptation capabilities

c. Job satisfaction

d. Profit ability

e. Resource search

In addition, there are also three approaches that can also be used as criteria to measure the effectiveness of an organization as stated by Lubis and Martani (1987:55):

a. Resource approach is to measure the effectiveness of inputs. The approach prioritizes the success of organizations to obtain resources, both physical and nonphysical that suit the needs of the organization.

b. The process approach is to see the effectiveness of the program implementation of all internal process activities or organizational mechanisms.

c. Goals approach where the center of attention to output, measures the success of the organization to achieve the results (output) that according to the plan.

While the measure of effectiveness according to Duncan in Steers (1985:53) are as follows:

a. Achieving the Achievement Goal is that the overall goal achievement effort should be viewed as a process. Therefore, in order to achieve the final goal more guaranteed, phasing is required, both in the sense of phasing out the achievement of its parts, as well as phasing in the sense of periodization. The achievement of the goal consists of several factors, namely: The period of time and the goal that is the concrete target.

b. Integration integration is a measurement of an organization's level of ability to socialize, develop consensus and communicate with a wide range of other organizations. Integration concerning the socialization process.

c. Adaptation adaptation is the organization's ability to adapt to its environment. Therefore, the benchmark of the procurement and filling process is used.

Daft (2010:13) explains the effectiveness of the organization can be expressed as the success rate of the organization in trying to achieve its goals and goals. There are several approaches that are most commonly used in measuring organizational effectiveness, one of which is through goal approach. What is meant by an organization's goal is a condition or condition that an organization wants to achieve. Goals can be interpreted as organizational goals, both long-term and short-term goals, as well as those of a particular part of an organization. The target approach suggests that the effectiveness of the organization is measured or assessed based on achievements or final results.

According to Gibson et.al in (Bungkaes 2013:46) Understanding Effectiveness is an Assessment made with respect to the achievements of individuals, groups and organizations. The closer their achievements are to the expected achievements of "standards" then they are judged to be more 
effective. According to Campbell J.P (1989:121) there are several ways of measuring effectiveness in general and most notably:

a. Program Success

The effectiveness of the program can be carried out with operational maturity in carrying out work programs that are in accordance with the objectives set before. The success of the program can be reviewed from the process and mechanism of an activity carried out in the field.

b. Goal Success

Effectiveness is reviewed from the point of view of achieving goals by focusing on the output aspect, meaning effectiveness can be measured by how far output levels in the organization's policies and procedures are to achieve the goals set.

c. Satisfaction with the program

Satisfaction is a criterion of effectiveness that refers to the success of the program in meeting the needs of the user. Users towards the quality of the products or services produced feel satisfaction. The more quality products and services provided, the higher the satisfaction felt by the user, the higher the profit for the institution.

d. Achievement of comprehensive goals

The extent to which the organization carries out its duties to achieve its goals. In this case it is a general assessment with as many single criteria as possible and results in a general assessment of the effectiveness of the organization.

\subsection{Village}

A common sense is a widely used notion by the general public about the fact or about the definition of a particular object discussed. In general, the village is defined by the community as a place to live a group of residents characterized by the use of grammar with a strong local accent, relatively low level of education, and generally the citizens have livelihoods in the field of agriculture or marine. In the General Dictionary of Bahasa Indonesia mentioned villages are (1) areas inhabited by a number of families who have a system of self-government (headed by the Village Chief), (2) a group of houses outside the city which is a unit of kampong, hamlet, (3) udik or hamlet (in the sense of inland area or opponent of the city), (4) place, land, area (Poerwadarminta, 2007:286).

Village based on the provisions of Article 1 number 1 of the Law of the Republic of Indonesia No. 6 of 2014 on villages defined as indigenous villages and villages or referred to by other names, hereby called villages, is the unity of legal communities that have territorial boundaries authorized to regulate and manage governmental affairs, the interests of local communities based on community initiatives, native rights, and/or traditional rights recognized and respected in the system of government of the Unitary State of the Republic of Indonesia.

Kartohadikoesoemo (1984:280) states that the village is a legal entity in which a powerful society resides and the community holds its own government. While the definition of village according to Ndraha (1981:33) is the lowest unit of government organization, has a certain territorial boundary, directly under the sub-district, and is a unit of the legal community that has the right to organize its household.

Handono (2005:132) states that villages are always associated with two main images, namely: (1) the village is sociologically seen as a community in a certain geographical unity that between them knows each other well with a relatively homogeneous pattern of life and relies directly on nature, so that its people are still largely dependent on nature, and (2) villages are often identified with power organizations. Through these glasses, the village is understood to be a power organization that politically has certain authority in the governance structure of the State.

The village is one of the autonomous regions at the lowest level of the regional autonomy hierarchy in Indonesia, as Nurcholis stated that, "the village is the lowest unit of government". One form of village government affairs that is the authority of the village is the financial management of the village. Village finances are all village rights and obligations that can be assessed with money, as well as everything in the form of money or in the form of goods that can be used as belonging to the village in connection with the exercise of rights and obligations (Nurcholis, 2011:81).

Sukriono (2008:1) expressed his opinion that the lowest government unit in Indonesia is a village. The concept of the village as a social entity is very diverse, which is in accordance with the intent and point of view that to be used in looking at the village. Village designation can be a concept 
without political significance, but it can also mean a political position and at the same time the quality of positions faced by other parties or forces.

The village has its own government, named after the village government. This village government is the administration of government affairs by the village government and the village community in regulating and managing the interests of the local community based on the origin and local customs recognized and respected in the system of the Government of the Unitary State of the Republic of Indonesia. The implementation of village government is a subsystem of the system of governance, so that the village has the authority to regulate and take care of the interests of its people.

Law No. 6/2014 on Village Article 18 explains that, village authority includes authority in the field of village government, implementation of village development, village community development, and village community empowerment based on community initiatives, origin rights, and village customs. Furthermore, article 19 is explained "Village Authority includes: authority based on the right of origin; local authority on a village scale; authority assigned by the government, provincial government, or district/city local government". The exercise of authority based on the rights of origin and local authority of the village scale as regulated and managed by the village. The implementation of the assigned authority and the implementation of the authority of other duties of the government, provincial local government, or local government of the district / city is taken care of by the village.

\subsection{Village-Owned Enterprises (BUMDes)}

According to Article 107 paragraph (1) letter (a) law No. 22 of 1999 states that the source of village income is one of the village's original income, which includes:

1. Village business results

2. The richness of the village

3. Self-help and participation results

4. The result of Cooperation; and

5. Other legitimate village native income.

The explanation of Article 107 paragraph (1) states that the empowerment of the village's potential in increasing village income is carried out, among others, with the establishment of villageowned enterprises, cooperation with third parties, and the authority to make loans. Furthermore, according to Article 213 paragraph (3) of Law No. 23 of 2014 concerning Local Government, which states that as an economic institution its venture capital is built on community initiatives and adheres to independent principles. This means that the fulfillment of bumdes business capital must be sourced from the community. Nevertheless, it does not close the possibility that BUMDes can apply for capital loans to outside parties, such as from the Village Government or other parties, even through third parties.

Another understanding of BUMDes is contained in Article 1 paragraph (6) of the Regulation of the Minister of Home Affairs No. 39 of 2010 on Village-Owned Enterprises, which states that BUMDes is a village business formed/established by the village government. Furthermore, BUMDes in Article 78 of Government Regulation No. 72 of 2005 on Villages stated that in order to increase the income of people and villages, the Village Government established a Village-Owned Enterprise (v. 1) the establishment of village-owned enterprises is determined in the Village Administration with the direction of the laws and regulations (paragraph 2). The form of village-owned enterprises must be legal (paragraph 3).

According to the Center for Development System Dynamics Study (2007), Village-Owned Enterprises (BUMDes) is a village enterprise managed by the community and village government in an effort to strengthen the village economy and be formed based on the needs and potential of the village. As one of the economic institutions operating in the country, BUMDes should have differences with economic institutions in general. This is intended so that the existence and performance of BUMDes is able to contribute significantly to the improvement of the welfare of villagers. In addition, so as not to develop a capitalist business system in the countryside that can result in the disruption of the values of public life.

According to the Center for Development System Dynamics Studies (2007), the management of BUMDes should be carried out using cooperative, participatory, emancipative, transparency, accountable, and sustainable principles, with member-base and self-help mechanisms run 
professionally, and independently. With respect to that, to build BUMDes it takes accurate and precise information about local characteristics, including the socio-cultural characteristics of its people and the market opportunities of the products (goods and services) produced.

BUMDes as a business entity built on community initiatives and adhere to independent principles, must prioritize the acquisition of capital from the community and pemdes. Nevertheless, it does not close the possibility that BUMDes can obtain capital from outside parties, such as from the District Government or other parties, and may even make loans to third parties, in accordance with the laws and regulations. Further arrangements regarding BUMDes will certainly be regulated through local regulations.

BUMDes was established with a clear purpose. These objectives, will be realized among others by providing services needs for productive businesses especially for poor people in rural areas, reducing the practice of rente (rente) and releasing money, creating equalization of opportunities to strive, and increasing the income of rural communities.

Another important thing is that BUMDes should be able to educate people to get used to saving, in a way that will be able to encourage the economic development of rural communities independently. The management of BUMDes, is predicted to continue to involve third parties that not only impact the villagers themselves, but also the community in a wider scope (district). Therefore, the establishment of BUMDes initiated by the community must still consider the existence of supporting village economic potential, tax payments in the village, and the compliance of the villagers to their obligations. All of this demands the involvement of the district government.

The characteristics of villagers who need to get the main services of BUMDes are:

1. Villagers who in adequately meet their life needs in the form of food, sandang and boards, most have an eye on the agricultural sector and conduct economic business activities that are informal businesses

2. Villagers whose incomes are very low, and find it difficult to set aside a portion of their income for further business development capital

3. Villagers who in this case can not meet their own life needs, so many fall into the hands of entrepreneurs who have stronger capital

4. Villagers whose business activities tend to be exacerbated by marketing systems that give capital owners the opportunity to be able to depress prices, so they tend to squeeze and enjoy most of the work of the villagers (Center for Development System Dynamics Studies, 2007).

Based on the above explanation, it can be concluded that BUMDes is very beneficial for the villagers, both have productive businesses and who do not have to jointly develop the economy of the villagers together.

BumDes character is in accordance with its main characteristics, underlying principles, mechanisms and management systems. In general, the establishment of BUMDes are intended to:

1. Improving service to the community (minimum service standards), in order to grow the efforts of the community in the village.

2. Empowering villages as an autonomous region with regard to productive efforts to alleviate poverty, unemployment and improving original village income.

3. Improving the independence and capacity of villages and communities in strengthening the economy in the village (Center for Development System Dynamics Study, 2007).

Based on the above explanation, it can be concluded that BUMDes has an important role in providing services to the villagers and as a contribution to increase the Village Native Income so as to support the development program in the village. The principles of management of BUMDes are important to be elaborated or outlined in order to be understood and perceived in the same way by the village government, members (capital investors), BPD, Government, and the community. There are 6 (six) principles in managing BUMDes, namely:

\section{Cooperative}

All components involved in BUMDes must be able to do good cooperation for the development and survival of its business. BUMDes is a pillar of economic activity in the village that serves as a social institution and commercial institution so that it requires synergistic cooperation between administrators, village governments, communities and related agencies. BUMDes as a social institution sided with its interests through its contribution in the provision of social services. While as 
a commercial institution aims to make a profit through the offering of local resources (goods and services) to the market. In carrying out its business cooperative principles should always be emphasized. BUMDes as a legal entity, formed based on applicable laws, and in accordance with the agreement struck in the villagers.

\section{Participatory}

All components involved in BUMDes must be willing to volunteer or be asked to provide support and contributions that can drive the progress of BUMDes efforts. Community participation in the management of BUMDes is highly expected and the role of the government in socializing and awareness to the villagers through the provincial government and/or district government about the importance of participating in BUMDes for the increase in the welfare of the community. Through the village government the community is motivated, made aware and prepared to build its own life.

BUMDes as a business capital economic institution is built on community initiatives and adheres to the principle of participation. This means that the fulfillment of bumdes business capital must be sourced from the community. Nevertheless, it does not close the possibility that BUMDes can apply for capital loans to outside parties, such as from the Village Government or other parties, even through third parties. This is in accordance with the regulation per law (Law 32 of 2004 on Local Government Article 213 paragraph 3). This explanation is very important to prepare the establishment of BUMDes, because the implications will come into contact with the regulation in the Regional Regulations (Perda) and village regulations (Perdes).

3. Emancipative

All components involved in BUMDes should be treated equally regardless of class, tribe, and religion. The mechanism of operation of BUMDes is handed over entirely to the villagers regardless of the background of any differences. Therefore, villagers need to be prepared in advance in order to accept new ideas about economic institutions that have two functions that are social and commercial. By remaining prepared that is considered most appropriate is centered on socialization, education, and training to parties interested in improving the standard of living of villagers.

4. Transparent

Activities that affect the interests of the general public should be known by all walks of life easily and openly. Transparency in the management of BUMS is necessary considering BUMDes is an economic institution operating in rural areas where the values that must be developed are honesty and openness. BumDes performance is able to make a significant contribution to the improvement of the welfare of villagers. In addition, in order not to develop a capitalist business system in the countryside that can result in the disruption of the values of public life.

The existence of BUMDes is expected to encourage the dynamic of economic life in the countryside. The role of the village government is to build relationships with the community to realize the fulfillment of minimum service standards as part of the development based community efforts of the village that is more empowered and meets the principle of transparency in its management to hold fast to the characteristics of the village and the values that live and are respected.

\section{Accountable}

All business activities must be technically and administratively responsible. The establishment and management of Village Owned Enterprises (BUMDes) is the embodiment of the management of the village's productive economy conducted accountablely. Therefore, it is necessary to make serious efforts to make the management of the business entity can run effectively, efficiently, professionally, independently and responsiblely. To achieve the goal of BUMDes is done by meeting the needs (productive and consumptive) of the community through the distribution of goods and services managed by the community and pemdes.

Fulfillment of this need is sought not to burden the community, considering BUMDes will be the most dominant village effort in driving the village economy. This institution is also required to be able to provide services to non members (outside the village) by placing prices and services that apply market standards. This means that there are institutional mechanisms/rules agreed together, so as not to cause economic distortions in the countryside due to businesses run by BUMDes.

6. Sustainable

Business activities must be developed and preserved by the community in bumdes containers. BUMDes was established with the clear goal of economic empowerment of rural communities. These 
objectives will be achieved by providing services for productive businesses, especially for the rural poor, reducing the practice of rente and money release, creating equal opportunities for trying, and increasing the income of rural communities. Another important thing is that BUMDes should be able to educate the public to get used to saving, in a way that will be able to encourage the economic development of rural communities independently and sustainably (Center for The Study of Development System Dynamics, 2007).

Related to the implementation of Village Fund Allocation (ADD), the process of strengthening the village economy through BUMDes is expected to be more empowered. This is due to the support of the village budget fund which is getting bigger. Thus enabling the availability of sufficient capital for the establishment of BUMDes. If this applies in line, there will be an increase in PADesa which can then be used for village development activities.

Based on the above description, it can be concluded that the important thing in the effort to strengthen the village economy is strengthening cooperation, building togetherness /establishing glutoment in all levels of village society, so that it becomes a steam engine in efforts to alleviate poverty, unemployment, and gain market access.

\section{Research methodology}

This research was conducted in Nekmese Village, South Amarasi District, Kupang Regency. The research method used in this study is a descriptive research method with a qualitative approach. A descriptive method is a method of examining the status of a human group, an object, a condition, a thought or a class of events today with the aim of systematically, factually and actually creating descriptions, images or paintings of the facts, traits and relationships between the phenomena investigated (Nazir, 2005:54). The primary data collected in this study is about the Effectiveness of BUMDes Implementation in Nekmese Village, the conditions in BUMDes that affect efforts to improve people's well-being, participation from the community, etc. obtained from research informants namely The Head of Nekmese Village, Director of BUMDes, Chairman of BUMDes business units, BUMDes administrators and community users of BUMDes while secondary data in the form of BUMDes accountability reports, BUMDes profiles, nekmese village population data which includes welfare level data, unemployment rate, etc. as well as other data related to BUMDes that researchers obtain from public media. The data collection techniques' used were interviews, observation, and documentation.

The steps in conducting data analysis according to Moleong (2010: 280) as follows:

1. Data Collection

Data collection is to search, record, and collect data objectively and as is in accordance with the results of interviews with research informants and documents in the field related to the impact of BUMDes policy on the welfare of the community in Nekmese Village.

2. Data Reduction

Data reduction is an activity of summarizing field records by sorting out the subject matter related to research issues, the summary of the field records is then systematically arranged to provide a sharper picture and facilitate re-tracking when data is needed again at any time. In this study, researchers reduced and sifted through observation, interview, and documentation data. Because the data obtained from the field is still complex and raw. Then researchers will only select data that is really relevant related to the impact of BUMDES on the welfare of the community in Nekmese Village.

\section{Display Data}

Display data is done by compiling a set of information that gives the possibility of drawing conclusions and taking actions. This data display is done by looking at the overall data obtained during the study related to the impact of BUMDes on the welfare of its people in Nekmese Village. The data is presented in the form of narrative text to explain the process that occurs from the stage of planning the development of BUMDes to the implementation stage as well as the impact on the welfare of nekmese villagers. From the data that has been presented is then processed based on the theories that have been put forward before to obtain a clear picture. The entire data that has been processed by the researcher is then collected into one by the researcher to then be presented until it reaches the conclusion stage 
4. Verification and Conclusion

Conclusion is the withdrawal of conclusions by departing from the formulation or purpose of research and then constantly examined to ensure its validity. Conclusions are also verified during the study, so verification is carried out throughout the study in line with triangulation thus guaranteeing the significance or significance of the results of the study. Conclusions are directed to the common things to know the answer to the problem. This research issue is related to the impact of BUMDes on the welfare of people in Nekmese Village, South Amarasi Sub-District and Kupang Regency.

Related to the implementation of Village Fund Allocation (ADD), the process of strengthening the village economy through BUMDes is expected to be more empowered. This is due to the support of the village budget fund which is getting bigger. Thus enabling the availability of sufficient capital for the establishment of BUMDes. If this applies in line, there will be an increase in PADesa which can then be used for village development activities.

Based on the above description, it can be concluded that the important thing in the effort to strengthen the village economy is strengthening cooperation, building togetherness /establishing glutoment in all levels of village society, so that it becomes a steam engine in efforts to alleviate poverty, unemployment, and gain market access.

\section{Results and discussion}

One of the objectives of BUMDes is community empowerment and One of the government strategies to facilitate the village in managing its existing potential is the issue of Law No. 6 of 2014 which states the village government is encouraged to have a Village-Owned Enterprises (hereby abbreviated as BUMDes) which is then further regulated in the Regulation of the Minister of Villages, Development of Disadvantaged Areas, and Transmigration of the Republic of Indonesia No. 4 of 2015 on the Establishment of Management and Management, and Dissolution of Village-Owned Enterprises. The establishment of BUMDes in addition to managing the assets, potential and resources in the local village, BUMDes also aims to increase the Village Native Income (PADesa) to improve the ability of.

The government has issued Village Ministerial Regulation No. 4 of 2015 on The Establishment, Management and Management, and Dissolution of Village-Owned Enterprises. This regulation is a guideline for regions and villages in the formation and management of BUMDes. BUMDes as a business entity, all or most of its capital is owned by the village through the direct inclusion of the village wealth, therefore, the development of BUMDes is a form of strengthening of the village economic institutions and is a tool of utilization of the local economy with various types of potential in the village, more than that BUMDes becomes the backbone of the village government economy to achieve the improvement of the welfare of its citizens.

The basis of the establishment of BUMDesa is based on the needs and potential of the village, as an effort to improve the welfare of the community. With regard to its planning and establishment, BUMDesa is built on community initiatives, and based on cooperative, participatory and transparency principles. In addition, the management of BUMDesa must be done professionally and independently. BUMDesa is a pillar of economic activity in the village that serves as a social institution and commercial institution. BUMDesa as a social institution sided with the interests of the community through its contribution in the provision of social services. So it can be concluded that BUMDes is a business entity managed by a group of people appointed and trusted by the provincially managed village government and family to multiply the potential of the village and advance the village economy with structured and managed. (Rutiadi, 2001 in Bachrein, 2010)

The management of BUMDes must be done professionally and independently so that in addition to being able to maintain its business continuity can also contribute to improving the village economy. One way is to optimize the operating profit generated by BUMDes. Operating profit generated will usually be allocated to meet capital needs and increase village income.

Long before the exit of Regulation of the Minister of Home Affairs No. 39 of 2010 which required the Local Government to issue regulations related to the establishment of BUMDes, the Government of Kupang Regency has issued Kupang District Regulation No. 7 of 2008 on The Procedure for Establishment of BUMDes in all villages in Kupang Regency. This government is the reference for the Nekmese Village Government to establish BUMDes at the same time with the 
Articles of Association and Household Organization (AD/ART). Nekamese Village Government then published Village Regulation No. 7 of 2017 on the Establishment of BUMDes which was also the legal basis of BUMDes Nekamese After the publication of Permendagri No. 39 of 2010 on the Procedure of Establishment of BUMDes, Kupang Regency Government then revised Kupang District Court No. 7 of 2008 with Kupang Regency Regulation Number 7 of 2010 concerning the Establishment of BUMDes. In line with that, the Nekmese village government issued village regulations on BUMDes No. 7 of 2017.

Recognizing the importance of legality aspect or legal basis as one of the conditions of developing an organization's business, Nekmese Village Issued Village Regulation No. 7 of 2017 so that bumdes implementation can run properly and have strong legality, so with the publication of Perdes Nekmese Village then the Village Government proposes Four Types of business units in BUMDES Sehatito immediately be able to carry out business activities to the four business units among them Clean Water Management, Cow Fattening, Minimarket and Pertamina Mini.

Based on the explanation above, to analyze the Effectiveness of The Implementation of Healthi Owned Enterprises (BUMDes) in Nekmese Village, South Amarasi District kupang regency authors used the effectiveness measurement theory of according to Campbell J.P (1989:121) there are several ways of measuring effectiveness in general and most prominently in accordance with the focus of research in the previous chapter, namely:

\subsection{Program success}

The effectiveness of the Implementation of Healthy State-Owned Enterprises (Bumdes) in Nekmese Village in The Southern Amarasi District of Kupang Regency can be carried out with operational implementation in carrying out work programs in accordance with the previously determined objectives. The success of the program can be reviewed from the process and mechanism of an activity carried out in the field.

By referring to the Regulation of the Minister of Villages, Development of Disadvantaged Areas, and. Transmigration No. 4/2015 on The Establishment, Management and Management, And Dissolution of Village-Owned Enterprises then the Operational Implementer of BUMDes Sehati has the task of managing and managing BUMDes Sehati in accordance with the Articles of Association and Household Budget. So that the Executor has an obligation to:

a. Implementing and developing BUMDes to become an institution that serves the economic needs and/or public services of the villagers;

b. Digging and harnessing the potential of the village's economic efforts to increase the Village's Original Income;

c. In cooperation with other economic institutions of the Village.

In carrying out the obligations of the Executor of Operations can appoint a Member of the Board of Executives in accordance with the capacity of the business field, especially in managing the recording and administration of business and operational functions of the business field. And can be assisted by employees according to needs and should be accompanied by a description of duties related to responsibilities, role division and other aspects of division of work.

The operational authorities are:

a. Make financial statements of all BUMDes business units every month;

b. To report on the development of the activities of state-owned enterprises every month;

c. To provide a report on the development of BUMDes business units to the villagers through village deliberations at least 2 (two) times in 1 (one) year.

Requirements for becoming an Operational Implementer include:

a. Villagers who have an entrepreneurial spirit;

b. Domiciled and settled in the Village for at least 2 (two) years;

c. Good personality, honest, fair, capable, and attentive to the economic efforts of the Village;

d. Minimum high school/Madrasah Aliyah/vocational school level or equivalent; 
The Executor of Operations may be dismissed on the grounds of:

a. Died;

b. Completed the service period as stipulated in the Articles of Association and Household Budget of state-owned enterprises;

c. Resigned;

d. Unable to perform the task properly thus hindering the development of the performance of stateowned enterprises;

e. Involved in criminal cases and has been designated as a suspect.

In its implementation in Nekmese Village, BUMDes Sehati has operational implementers have followed all the processes and mechanisms of activities that have been established in accordance with AD/RT BUMDes Sehati. In addition, it is also known that the operational executors of BUMDes Sehati also have the ability to develop the economic potential of the community to meet the goals set but in contrast to the in-depth observations that the authors did where it was found that operational implementers often do not provide socialization to the communities given assistance. Human resources are also considered inadequate but of all that it is known that there is complaint related to the financial statements of all business units of BUMDes Sehati that must be reported every month. There are no complaints related to the progress report of the activities of BUMDes Sehati business units every month as well as the absence of complaints related to the report on the development of BUMDes Sehati business units to the villagers through village deliberations.

\subsection{Goal success}

Effectiveness is reviewed from the point of view of achieving the goal by focusing on the output aspect, meaning that effectiveness can be measured by how far the level of output in the policies and procedures of the organization that in the context of this study is the Village Owned Enterprises (Bumdes) Sehati In Nekmese Village South Amarasi Sub-District has achieved the goals that have been set.

There are several activity programs initiated by BUMDes Sehati Nekmese Village, namely clean water management, cattle fattening farms, minimarkets, mini-pertamina in the Nekmese village face the following phenomenon:

1. Less effective water management

a. The lack of understanding of BUMDes Sehati Nekmese Village towards the management of clean water resulted in the process of distributing clean water to the community which is still very limited and the distribution of water to the community is still manually, where 12 clean water reservoirs are built and the community takes it directly using jerry cans and buckets

b. There are no technical personnel who understand and are reliable in the operation of clean water to the reservoir.

c. Insufficient budget for maintenance costs. Since 2018 the Budget provided for the financing of clean water works amounted to Rp.214.83.000, - (Two Hundred And Fourteen Million Nine Hundred Eighty-Three rupiah) but the budget sourced from THIS ADD has not been sufficient for the purchase of pipes and water meters that can be distributed to the homes of residents.

2. Cattle farming and fattening

It is known that cattle farming farms are faced with several problems including feed caused by the use of feed inputs that come from nature so that during the dry season it will be very difficult to find feed. The long dry season of about 8-9 months causes feed production in grazing land and forest land to dry out so that it affects the growth of beef cattle in Nekamese Village, simple farm management causes fattening of cows in Nekmese Village takes a long time with an average fattening up to 18 months while short fattening of cows with good farm management only lasts 3-4 months. This causes the increase in the weight of the beef cow in Nekmese Village to only reach 0.2-0.4 $\mathrm{kg} / \mathrm{tail}$ while the optimal increase in cattle weight for balinese cows can reach $0.3-0.6 \mathrm{~kg} / \mathrm{tail}$.

3. Minimart

In order to develop the economic potential of the village, Nekmese Village since 2017 then manages the Village-Owned Enterprises (BUMDes) with a minimarket business unit. The main purpose of BUMDes Development in the form of convenience stores or convenience stores is 
implemented to serve retail-to-retail needs for residents in the local village area. But in its implementation it is known that there are obstacles that are such as obstacles experienced by many BUMDes who choose supermarket businesses. Such constraints are potential markets or potential buyers. With the offtaker (willing to buy) then the market problem can be solved. Nekmese villagers still do not have the culture to buy in supermarkets on the grounds of remote access, relatively unreachable goods prices and low economic capabilities so that products from BUMDes businesses in the form of supermarkets in Nekmese Village have not been absorbed optimally.

4. Pertamina Mini

There are several problems that occur, in the management of Pertamina Mini in Nekmese Village as follows:

a. Access to a large amount of fuel must be obtained through the creation of a license that takes 1 week

b. Sometimes Faulty Machines

c. The absence of skilled technical personnel in repairs does not exist

Based on the various problems mentioned above, it can be stated that the achievement of the target stipulated by BUMDes Desa Sehati in its implementation still has many shortcomings so that it can not yet be declared effective.

\subsection{Satisfaction with the program}

Satisfaction is a criterion of effectiveness that refers to the success of the Program of HealthOwned Enterprises (Bumdes) in Nekmese Village of South Amarasi Sub-District in meeting the needs of the community. Satisfaction is felt by the people of Nekmese Village of South Amarasi SubDistrict towards the quality of products or services produced. The more quality products and services provided, the satisfaction felt by the nekmese villagers of South Amarasi Sub-District is higher, so it can create benefits for the institution.

The satisfaction of the program that is a criterion for the effectiveness of the success of the Health-Owned Enterprises (Bumdes) program in Nekmese Village, South Amarasi Sub-District in meeting the needs of the community can be declared ineffective. The authors stated that it has not been effective because of the various results of the interview found the fact that the majority of nekmese villagers who received assistance from BUMDes Sehati still expressed dissatisfaction with the performance of BUMDes Sehati. Furthermore, to confirm the statement of masayarakat Desa Nekmese, the author made an in-depth observation and in the observation the author found the same facts as the public statement so that this could cause harm in terms of public confidence in the performance of BUMDes Sehati.

\subsection{Achievement of comprehensive goals}

The extent to which Sehati Village-Owned Enterprises (Bumdes) in Nekmese Village of South Amarasi Sub-District carry out its duties to achieve the goal. In this case it is a general assessment with as many single criteria as possible and results in a general assessment of the effectiveness of the organization.

Related to the achievement of the overall goal carried out by BUMDes Sehati Nekmese Village it is known that in its implementation at the micro level which in this case is the nekmese village community can still not be declared effective because there are still various shortcomings that accompany each program.

Achieving goals is an activity that has a purpose by using planning, directing, organizing, and resource control to achieve goals effectively and efficiently. Effective means that goals can be achieved according to planning. From this explanation, the author can state that the overall achievement of the objectives of BUMDes Sehati Nekmese Village cannot be declared effective.

\section{Conclusion}

The effectiveness of the Implementation of Bumdes Sehati Village-Owned Enterprises in Nekmese Village south Amarasi District kupang regency was analyzed using the effectiveness measurement criteria of Campbell J.P (1989:121) which stated that there are several ways of 
measuring effectiveness in general and most prominently and can be drawn conclusions as follows:

1. Program success

Operational implementers often do not provide socialization to the community given assistance, human resources are also considered inadequate so that it contributes to the ineffective success of various BUMDes Sehati programs in Nekmese Village.

2. Goal success

The achievement of the target stipulated by BUMDes Desa Sehati in its implementation still has many shortcomings so it cannot yet be declared effective.

3. Satisfaction with the program

Sehati Village-Owned Enterprises (Bumdes) in Nekmese Village, South Amarasi Sub-District in meeting the needs of the community can be declared ineffective. The majority of Nekmese villagers who received assistance from BUMDes Sehati still expressed dissatisfaction with the performance of BUMDes Sehati.

4. Achievement of comprehensive goals

The achievement of the overall goal carried out by BUMDes Sehati Nekmese Village in its implementation at the micro level, which in this case is the Nekmese villagers, still cannot be declared effective because there are still various shortcomings that accompany each BUMDes Sehati's program.

\section{References}

Abdurahmat. (2008). Efektivitas organisasi Edisi Pertama. Jakarta. Airlangga

Bachrein, Saeful. (2010). Pendekatan desa membangun di Jawa Barat: strategi dan kebijakan pembangunan perdesaan. Jawa barat. Jurnal Analisis Kebijakan Pertanian, 8(2), 133-149.

Bernard, I, Chester. (1992). Organisasi dan manajemen, struktur, perilaku dan proses. Jakarta: Gramedia

Bungkaes, H. R., Posumah, J. H. (2013). Hubungan efektivitas pengelolaan program raskin dengan peningkatan kesejahteraan masyarakat di Desa Mamahan Kecapatan Gemeh Kabupaten Kepulauan Talaud. Journal "Acta Diurna".

Campbell. J.P. (1989). Riset dalam efektifitas organisasi. Terjemahan Sahat Simamora. Jakarta: Erlangga

Daft. (2010). Era baru manajemen. Jilid 1. Edisi ke Sembilan Salemba Empat. Jakarta

Handayaningrat, Soewarno. (1994). Pengantar studi ilmu administrasi dan manajemen. Jakarta. CV.Haji Masagung

Handono, E. B. (2005). Membangun tangung gugat tata pemerintahan desa. In Forum Pembangunan Pembaharuan Desa(FPPD), Yogyakarta.

Hidayat. (1986). Teori efektivitas dalam kinerja karyawan. Yogyakarta. Gajah Mada University Press. Kartohadikoesoemo, Soetardjo. (1984). Desa. Jakarta. Balai Pustaka.

Kemendesa.go.id. (2017). Bumdes dan Prukades bakal jadi lokomotis ekonomi desa. https://kemendesa.go.id/berita/view/detil/2250/bumdes-dan-prukades-bakal-jadi-lokomotifekonomi-desa . Diakses pada 21 Sesember 2020.

Lubis, S.M. Hari dan Huseini, Martani. (1987). Teori organisasi: suatu pendekatan makro. Jakarta: Pusat Antar Universitas Ilmu-Ilmu Sosial.

Moleong, L.J. (2010). Metodologi penelitian kualitatif. Bandung: Remaja Rosda Karya.

Nazir, Moh. (2005). Metode penelitian. Jakarta: Ghalia Indonesia.

Ndraha. (1991). Pembangunan masyarakat. Jakarta. Rineka Cipta.

Nurcholis, Hanif, (2011). Pertumbuhan dan penyelenggaraan pemerintahan desa. Jakarta : penerbit ERLANGGA

Pemerintah Desa Nekamese. (2017). Peraturan Desa Nomor 7 Tahun 2017 tentang Pembentukan BUMDes. Sekertariat Desa Nekamese.

Pemerintah Kabupaten Kupang. (2008). Peraturan Daerah Kabupaten Kupang Nomor 7 Tahun 2008 tentang Tata Cara Pembentukan BUMDes di Seluruh Desa di Kabupaten Kupang.

Pemerintah Kabupaten Kupang. (2010). Peraturan Kabupaten Kupang Nomor 7 Tahun 2010 tentang Pembentukan BUMDes. 
Pemerintah Republik Indonesia. (1999). Undang-Undang Republik Indonesia Nomor 22 Tahun 1999 tentang Pemerintahan Daerah. Sekertariat Negara. Jakarta.

Pemerintah Republik Indonesia. (2004). Undang-Undang Republik Indonesia Nomor 32 Tahun 2004 tentang Pemerintahan Daerah. Lembaran Negara Republik Indonesia tahun 2004 Nomor 125. Sekertariat Negara. Jakarta.

Pemerintah Republik Indonesia. (2005). Peraturan Pemerintah No. 72 Tahun 2005 tentang Desa. Lembaran Negara Republik Indonesia Tahun 2005 Nomor 158. Sekertariat Negara. Jakarta.

Pemerintah Republik Indonesia. (2010). Peraturan Menteri Dalam Negeri Nomor 39 Tahun 2010 tentang Badan Usaha Milik Desa. Berita Negara Republik Indonesia Tahun 2010 Nomor 316. Sekretariat Negara. Jakarta.

Pemerintah Republik Indonesia. (2014). Undang-Undang Republik Indonesia No. 6 Tahun 2014 tentang Desa. Lembaran Negara Republik Indonesia. No.7. Sekretariat Negara.Jakarta.

Pemerintah Republik Indonesia. (2014). Undang-Undang Republik Indonesia Nomor 23 Tahun 2014 tentang Pemerintah Daerah. Lembaran Negara Republik Indonesia Tahun 2014 Nomor 244. Sekertariat Negara. Jakarta.

Pemerintah Republik Indonesia. (2015). Peraturan Menteri Desa PDTT Nomor 4 tahun 2015 tentang Pendirian, Pengurusan, dan Pengelolaan dan Pembubaran Badan Usaha Milik Desa. Berita Negara Republik Indonesia Tahun 2015 Nomor 296. Sekertariat Negara. Jakarta.

Poerwadarminta. (2007). Kamus Umum Bahasa Indonesia. Jakarta. PN Balai. Pustaka.

Pusat Kajian Dinamika Sistem Pembangunan FE Brawijaya. (2007). Buku Panduan Pendirian dan Pengelolaan Badan Usaha Milik Desa (BUMDes). PP RPDN.

Silalahi, Ulber. (2015). Metode penelitian sosial. Jakarta: Refika Aditama.

Steers, M. Richard. (1985). Efektifitas organisasi. Jakarta: Erlangga.

Sukriono, D. (2008). Politik hukum pemerintahan desa di Indonesia. Jurnal Konstitusi, 1(1).

Tangkilisan, Nogi Hessel. (2005). Manajemen publik. PT. Gramedia Widiasarana Indonesia : Jakarta.

Widjaja. (2003). Otonomi daerah. Jakarta: PT raja Grafindo Persada. 